\title{
The Relationship Between Human Development, Tourism and Economic Growth: Evidence From Malaysia
}

\author{
Yan-Teng Tan ${ }^{1}$, Pei-Tha Gan ${ }^{1}$, Mohd Yahya Mohd Hussin ${ }^{1} \&$ Norimah Ramli ${ }^{1}$ \\ ${ }^{1}$ Department of Economics, Faculty of Management and Economics, Universiti Pendidikan Sultan Idris, Tanjong \\ Malim, Malaysia \\ Correspondence: Pei-Tha Gan, Department of Economics, Faculty of Management and Economics, Universiti \\ Pendidikan Sultan Idris, 35900 Tanjong Malim, Perak, Malaysia. E-mail: gan.pt@ fpe.upsi.edu.my
}

Received: October 10, 2019

Accepted: November 5, 2019

Online Published: December 23, 2019

doi:10.5430/rwe.v10n5p96

URL: https://doi.org/10.5430/rwe.v10n5p96

\begin{abstract}
A remarkable feature of empirical studies is that not many research works investigate the relation between human development and tourism. Although gross domestic product may replace human development to measure economy progress and human well-being in relation to tourism, however, this definition, is narrow, limits to economic side, and ignores the social and cultural factors. To overcome this shortcoming, this study examines the relationship between human development, tourism and economic growth in Malaysia. By using different cointegration approaches, the results indicate that tourism is positively related to human development in the long run. The finding suggests that the known relationship may serve as a guide to policy makers to achieve better development of social and cultural in order to promote the growth.
\end{abstract}

Keywords: human development, tourism, cointegration, vector error correction

JEL classification: $\mathrm{O} 15, \mathrm{O} 10, \mathrm{C} 32$

\section{Introduction}

Tourism industry has developed rapidly in recent years and made a great contribution to economic growth in Malaysia. A fundamental literature review tourism-led growth hypothesis has been conducted by Sinclair (1998), thereafter, the number of studies on this topic has increased intensely. Although the country's economic health has typically been measured by using gross domestic product (GDP) in many empirical works. The use of human development as a measure of the country's economic health cannot be ignored because it may provide a better performance than GDP; human development can better observe the well-being of society. For example, in Figure 1, human development index (HDI) holds steady rather than GDP in the range between 0.7 and 0.8 from year 2005 to 2015 (United Nations, 2018); the Malaysia's GDP and HDI are taken into account because this paper uses Malaysia as a sample of study. (Note 1) Unlike the GDP movements, the HDI movements may give an overall infer of economic development and it enables comparison studies about issue on economic welfare; the HDI includes life expectancy, education and income levels. Therefore, a puzzle remains as to whether research in area can improve our knowledge and correctness of the relation between human development and tourism (Shafai et al., 2019). 


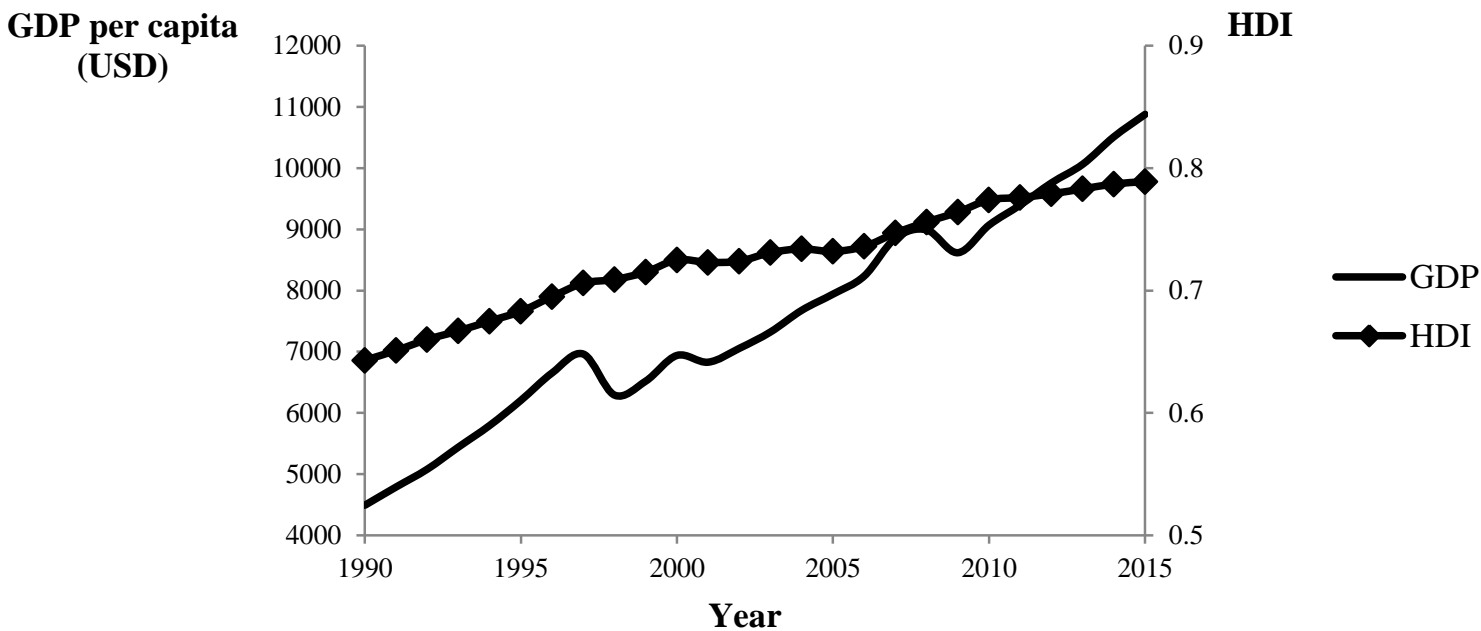

Figure 1. Comparison between HDI and GDP per capita in Malaysia during period 1990-2015

Sources: HDI obtained from United Nations (2018); GDP data obtained from World Bank Data (2018).

A remarkable feature of empirical studies is that not many research works investigate the relation between human development and tourism; note that this paper assumes that human development is a proxy of the country's economic health. Although commonly GDP may replace human development to measure economy progress and human well-being in relation to tourism, however, this definition, is narrow, limits to economic side, and ignores the social and cultural factors. For instance, Vanegas and Croes (2003) argue that the connection between the tourism and economic growth is positive in Aruba, especially, those countries are small and specializing in tourism activities. Othman and Salleh (2008) suggest that tourism-led economic growth hypothesis is valid in Malaysia and Singapore while economic-drive tourism growth is found for Thailand and Indonesia by using Johansen Juselius cointegration method. Lean, Chong and Hooy (2014); Mohamed, Rasheli \& Mwagike (2018) find that the existence of tourism-led economic growth in the case of Singapore. They also find that the existence of economic-led tourism in the case of Malaysia with two control variables, international trade and exchange rate are included in the model to enhance the specification. By examining tourism infrastructure and facilities in promoting the economic growth, Kadir and Karim (2012) suggest the presence of cointegration between international tourism receipts from ASEAN 5 countries and real economic growth in Malaysia by using panel time-series approach.

One may consider the literatures of Tang and Tan (2015) which verify the validity of the tourism-led growth hypothesis in Malaysia using a multivariate model derived from the Solow growth theory. Further, causality test is employed in the study of Lean and Tang (2010) to demonstrate the validity and stability of the tourism-growth causality relationship in Malaysia to affirm that the tourism-led growth hypothesis is valid and stable over time for the Malaysia economy. By applying the panel cointegration approach, Kum, Aslan and Gungor (2015); Zafarullah (2018) conclude that tourism arrivals has positive effect on GDP growth in N-11 countries. In addition, unidirectional causality from economic growth to tourism is valid confirming economic driven tourism growth hypothesis. The findings of Suresh and Senthilnathan (2014) reveals that there is a unidirectional causality between economic growth and post-war tourism earning according to Keynesian approach by using error correction mechanism. Its international tourism can be accepted as an exogenous component of aggregate demand that has a positive effect on income, employment and so on, thus leading to economic growth through the multiplier. However, this tourism-led growth hypothesis is static and does not agree an inference of the long-term impact of tourism development in seven countries, namely Spain, Italy, Tunisia, Cyprus, Croatia, Bulgaria and Greece by using panel granger causality method (Aslan, 2013; Maciuliene, Skarzauskiene \& Botteldooren, 2018).

The motivation of this paper is that tourism may affect the human development. Because tourism may contribute to a broader cultural understanding by creating awareness respecting the diversity of cultures and ways of life (Nana, 2017), it is no doubt to explore the tourism-led development hypothesis (Biagi, Ladu \& Royuela, 2017; Tanoos, 2017). Besides creating employment opportunities, the presence of the tourists in domestic countries may induce ideas and 
knowledge to firms in increasing their productivity (Marrocu \& Paci, 2011). Moreover, the arrival of foreign tourists can promote the education of local residents by bringing them into contact with other people and culture especially in developing countries (Ankomah \& Compton, 1990). Yet, tourist arrivals may present a negative impact on human development by reducing the quality of life of the population as tourist may create traffic congestion, noise and crowds (Andereck, Valentine \& Knopf, 2007). Considering the contributions of tourism on human development, the lack/absence of tourism activities may deficient the human development that eventually lead to discontinue progress and increases the risk of economic and social stagnation (Rivera, 2017; Njegovanovic, 2018).

The objective of this paper is to examine the relationship between human development, tourism and economic growth in Malaysia, such that the known relationship may serve as a guide to policy makers to achieve better development of social and cultural in order to promote the growth. This study extends the previous work of human development model proposed by Sen (1999) by encompassing the factor of tourism; this model is knowns as capability approach. The model can be used to study welfare economics that may include the standard of living, wellbeing, and poverty. This study adopts Malaysia as a sample study. Note that because tourism is the second leading private investment contributor and third largest source of income in Malaysia, one must enhance the tourism industry for high growth purpose (Department of Statistic Malaysia, 2016). This study examines the relationship between human development, and tourism and economic growth by using two cointegration methods, namely Johansen-Juselius cointegration and vector error correction model (VECM). The rest of the paper is arranged as follows. The following section discusses the model and methodology. Section three discusses the results. Section four concludes the study.

\section{Model and Methodology}

\subsection{Model Specification}

The study employs the annual data from 1998-2015 to examine the relationship between human development, tourism and economic growth in Malaysia, by considering the model as below:

$$
\mathrm{HDI}_{\mathrm{t}}=\beta_{0}+\beta_{1} \text { TOUR }_{\mathrm{t}}+\beta_{2} \mathrm{GDP}_{\mathrm{t}}+\varepsilon_{t}
$$

where, HDI represents human development index, TOUR represents tourism receipts in US Dollar, and GDP per capita in US Dollar represents economic growth; the HDI is a geometric mean of normalized indices that measured by a combination anchor of human development, namely being knowledgeable, a decent standard of living, and healthy and long life. (Note 2) All data (i.e., GDP and TOUR) are obtained from World Bank (2018), except HDI is obtained from United Nations. The following subsection discusses the methodology of the study.

\subsection{Johansen-Juselius Cointegration Test}

To test the long run relationship between TOUR, HDI and GDP, we applied Johansen and Juselius (1990) cointegration test. In indicating $X$ as a vector of study variable, the JJ test is demonstrated as below:

$$
\Delta X_{t}=\mu_{t}+\Pi X_{t-k}+\Gamma_{1} \Delta X_{t-1}+\cdots+\Gamma_{k-1} \Delta X_{t-k+1}
$$

where, $X_{t}$ is a column vector of TOUR, HDI and GDP; $\Pi$ indicates the long run relationship between the variables in $X_{t}$ process, which can be well-defined as:

$$
\Pi=\alpha \beta^{\prime}
$$

where, $\alpha$ reveals the speed of adjustment in $\Delta X_{t}$ and $\beta^{\prime}$ indicates log run coefficients of the cointegrating vector. The rank of $\Pi$ refers to the number of cointegrating relationship. Two likelihood ratio tests are performed, namely trace test and maximum eigenvalue test in order to decide the rank of $\Pi$. Here are the expected results: there is no cointegration in the long run if the rank of $\Pi=$ zero; the variables in $X_{t}$ are stationary if full rank is obtained; whereas, it suggests that there is multiple cointegrating vectors in the system if the rank of $\Pi$ is $0<\Pi<p$.

The null hypothesis of Johansen of no cointegration in contradiction of the alternative of cointegration are applied for trace test and maximum eigenvalue test. Besides, the null hypothesis of the number of cointegrating vector less than or equal to $r$ is used in the trace statistic tests and illustrated as follows:

$$
\text { Trace }=-T \sum_{i=r+1}^{n} \ln \left(1-\lambda_{i}\right)
$$

On the other hand, the null hypothesis of number of cointegrating vectors, $r$ against alternative hypothesis of $r+1$ cointegration vectors are employed in the maximum eigenvalue statistic tests and showed as follows:

$$
\text { maximum eigenvalue }=-T \ln \left(1-\lambda_{r+1}\right)
$$

where, $\lambda_{i}$ is the estimated value for the $\mathrm{i}^{\text {th }}$ ordered eigenvalue from the $\Pi$ matrix. We expect to reject null hypothesis for both statistical tests when the test statistics are larger than the critical values. 


\subsection{Vector Error Correction Model}

The VECM can use Eq. (1) to examine the long-run cointegration relationships between HDI, TOUR and GDP. The common advantages by using VECM are that the VECM is a restricted vector autoregressive model with nonstationary series which are cointegrated and that can limit the long-run behavior of endogenous variables. Typically, the VECM is written as below:

$$
\Delta y_{t}=\alpha e c m_{t-1}+\sum_{i=1}^{p-1} \tau_{i} \Delta y_{t-i}+\mu_{t}
$$

where $y_{t}$ is $\left[y_{1_{t}}, y_{2_{t}}, \ldots, y_{i_{t}}\right]^{\prime}$ as i-dimensions of stochastic time series in order integration of one and ecm $e_{t-1}$ is the error correction term (Note that the error correction term equals to zero in the long run equilibrium and becomes non-zero when $y$ deviates from the long run. The term includes the previous information of the variables that usually is expected to be significant with negative sign, i.e., the variable is able to return to the equilibrium in the long-run). From Eq. (6), the VECM assumes that the roles of the exogenous time series do not exist. In line with the cointegration examination, one can further the analysis of the VECM to granger causality, variance decomposition and impulse response.

\section{Results Interpretation}

Prior to the cointegration analysis, the section begins with unit root tests, namely augmented Dickey-Fuller (ADF) and Philips Perron (PP) tests. As can be seen from Table 1, all the variables, namely $\mathrm{HDI}_{\mathrm{t}}, \mathrm{TOUR}_{\mathrm{t}}$ and $\mathrm{GDP}_{\mathrm{t}}$ are integrated at first difference by using ADF test. Similarly, PP test provides the results of rejecting $\mathrm{H}_{0}$ of unit root and illustrates that all the variables are stationary at first differencing. The study then investigates the existence of long-run cointegrating relationships (i.e., common trend) between the variables.

Table 1. Tests of unit root

\begin{tabular}{lll}
\hline Variables & ADF & PP \\
\hline HDI $_{\mathrm{t}}$ & -3.8417 & -2.6005 \\
$\Delta \mathrm{HDI}_{\mathrm{t}}$ & $-3.2815^{* *}$ & $-3.7647^{* *}$ \\
& & \\
TOUR $_{\mathrm{t}}$ & -1.8683 & -2.0436 \\
$\Delta \mathrm{TOUR}_{\mathrm{t}}$ & $-3.3543^{*}$ & $-3.1408^{*}$ \\
& & \\
$\mathrm{GDP}_{\mathrm{t}}$ & -2.6654 & -2.2724 \\
$\Delta \mathrm{GDP}_{\mathrm{t}}$ & $-5.2636^{* * *}$ & $-10.8271^{* * *}$ \\
\hline
\end{tabular}

Notes: $*, * *$ and $* * *$ indicate significance at $10 \%, 5 \%$ and $1 \%$ levels, respectively; $\Delta$ represents first difference level

The study begins with the Johansen-Juselius Cointegration test. The results obtained from the Johansen-Juselius cointegration test are presented in Table 2; the test uses an optimal lag length of two for estimations. Both the results of trace and maximum eigenvalue tests illustrate that there exist two cointegrated relationship at $5 \%$ significance level.

Table 2. Johansen-Juselius cointegration test

\begin{tabular}{lcc}
\hline Johansen Cointegration Test & Trace Statistic $\left(\lambda_{\text {trace }}\right)$ & Maximum Eigenvalue $\left(\lambda_{\max }\right)$ \\
\hline Hypothesized no. of CE(s) & & \\
$r=0$ & $48.9268^{* *}$ & \\
$r \leq 1$ & $21.5258^{* *}$ & $27.4011^{* *}$ \\
$r \leq 2$ & 0.43558 & $21.0902^{* *}$ \\
& & 0.43558 \\
\hline
\end{tabular}

Notes: ** denotes rejection of the hypothesis at $5 \%$ level of significance. 
On the other hand, Eq. (7) is estimated from the VECM, which normalizing the coefficient of HDI to one. The Eq. (7) suggests that the coefficient of tourism is positively and statistically significant affect HDI at $1 \%$ level. The long run coefficient of $\mathrm{HDI}_{\mathrm{t}}$ with regard to TOUR $\mathrm{R}_{\mathrm{t}}$ is found to be 0.2035 , i.e., $1 \%$ increase in $\mathrm{TOUR}_{\mathrm{t}}$ will cause in $0.2035 \%$ in $\mathrm{HDI}_{\mathrm{t}}$.

$$
\mathrm{HDI}_{\mathrm{t}}=-1.9991+0.2035 \mathrm{TOUR}_{\mathrm{t}-1} * * *-0.3333 \mathrm{GDP}_{\mathrm{t}-1}
$$

After estimating the long run VECM model, it is obvious that the error correction approach is feasible, and that the deviation from long-run equilibrium may influence the HDI (sees Table 3). The HDI adjusts at the speed of 4.3\% every year to restore back to the long-run equilibrium. To provide robust results, in line with the VECM estimates, we further perform the granger causality test, decomposition of variance, and impulse response.

Table 3. Granger causality Test based on VECM

\begin{tabular}{|c|c|c|c|c|}
\hline \multirow{3}{*}{ Dependent variables } & \multicolumn{3}{|c|}{ Independent variables } & \multirow{3}{*}{$\mathrm{ECT}_{\mathrm{t}-1}$ coefficients } \\
\hline & \multicolumn{3}{|c|}{$x^{2}$ statistics } & \\
\hline & $\Delta H D I$ & $\Delta T O U R$ & $\triangle G D P$ & \\
\hline$\Delta H D I$ & - & 0.0997 & $8.2118 * *$ & $-0.0431 *$ \\
\hline$\triangle T O U R$ & 2.8187 & - & 2.9405 & 1.1759 \\
\hline$\triangle G D P$ & $17.6819 *$ & $6.3147 * *$ & - & $-0.2791 * *$ \\
\hline
\end{tabular}

Notes: * and ** indicate significance at 5\% and $1 \%$ levels, respectively.

Results in Table 3 seem to suggest that GDP causes HDI and vice versa. Tourism also plays an important role in stimulating GDP in the short run at 5\% significance level. The result is consistent with Lean et al. (2014). On the other hand, in Table 4, by using 10 years horizons, $87.91 \%$ of the forecast error variance of HDI is explained by its own shock. Besides, the variance from shocks to tourism and GDP are self-explained, that is $89.67 \%$ and $11.1 \%$, respectively. However, shocks to HDI are explained by tourism (5.5\%) and GDP (6.57\%) after 10 years.

Table 4. Decomposition of variance

\begin{tabular}{llll}
\hline Period & HDI & TOUR & GDP \\
\hline Variance Decomposition of HDI & & & \\
1 & 100.00 & 0.00 & 0.00 \\
2 & 96.53 & 0.07 & 3.39 \\
3 & 93.93 & 0.31 & 5.74 \\
4 & 90.91 & 3.46 & 5.61 \\
5 & 87.35 & 6.71 & 5.93 \\
10 & 87.91 & 5.50 & 6.57 \\
Variance Decomposition of TOUR & & & \\
1 & 1.15 & 98.84 & 0.00 \\
2 & 2.11 & 96.42 & 1.46 \\
3 & 1.86 & 96.50 & 1.62 \\
4 & 3.15 & 95.24 & 1.59 \\
5 & 4.11 & 94.20 & 1.67 \\
10 & 7.58 & 89.67 & 2.73 \\
Variance Decomposition of GDP & & &
\end{tabular}




\begin{tabular}{llll}
1 & 32.59 & 28.40 & 38.99 \\
2 & 30.91 & 52.77 & 16.30 \\
3 & 50.54 & 36.90 & 12.55 \\
4 & 60.81 & 25.47 & 13.70 \\
5 & 61.98 & 25.42 & 12.59 \\
10 & 71.00 & 17.89 & 11.10 \\
\hline
\end{tabular}

Notes: Figures in first column refer to time horizons. All other figures are rounded to two decimal places.

Finally, the response paths to these various shocks are analyzing by using graphical presentation. The results of the impulse response are presented in Figure 2(a) and Figure 2(b). Response of HDI to tourism takes longer period to fade out if compared with the shocks to GDP. After 3 year horizons, HDI return to its pre-shock level for the effects of the shock to GDP. Moreover, one standard deviation shock to tourism leads to a 0.005 units increase in the change in the logarithm of HDI after 5 years, which corresponds to $0.05 \%$ points increase in the growth of HDI.

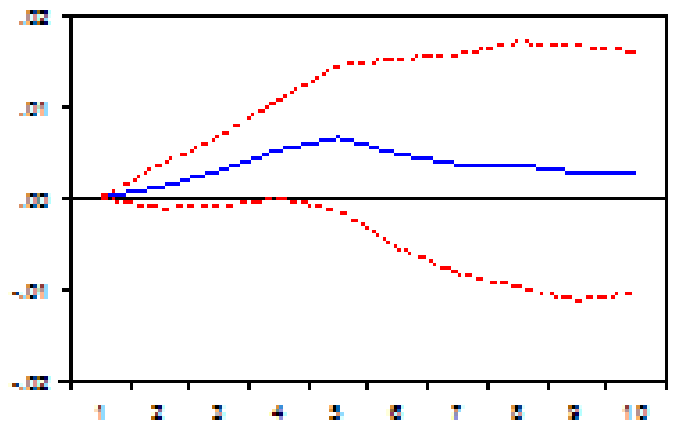

Figure 2(a). Response of LHDI to LTOUR

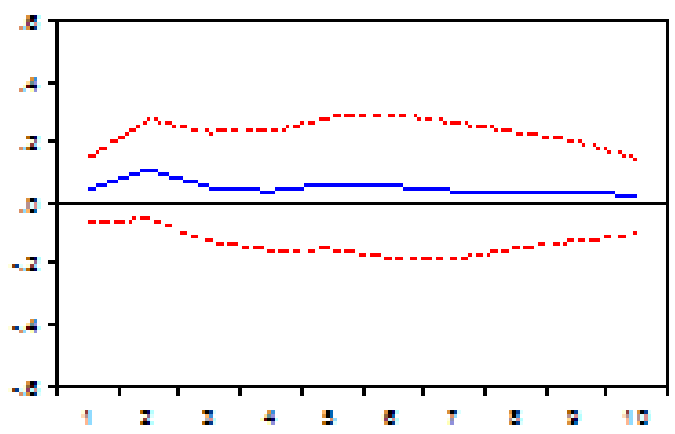

Figure 3(a). Response of LTOUR to LHDI

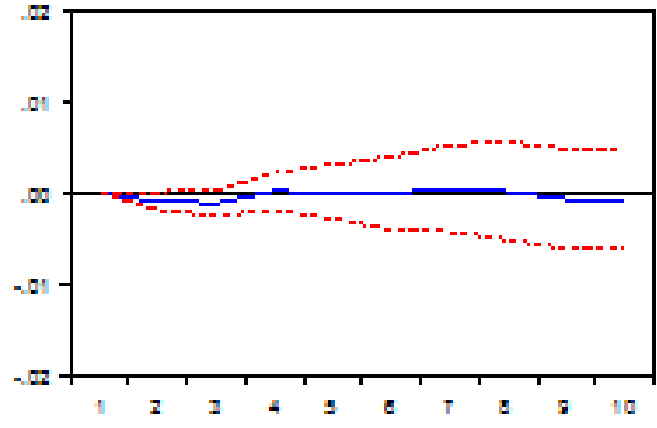

Figure 2(b). Response of LHDI to LGDP

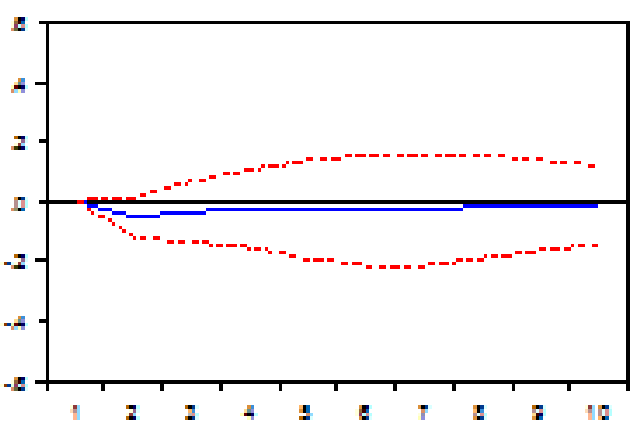

Figure 3(b). Response of LTOUR to LGDP 


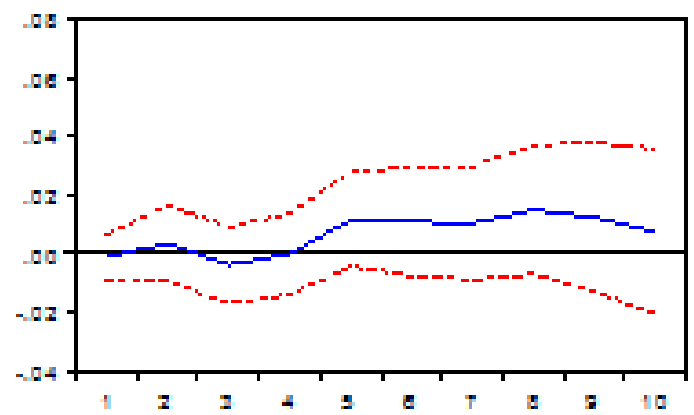

Figure 4(a). Response of LGDP to LHDI

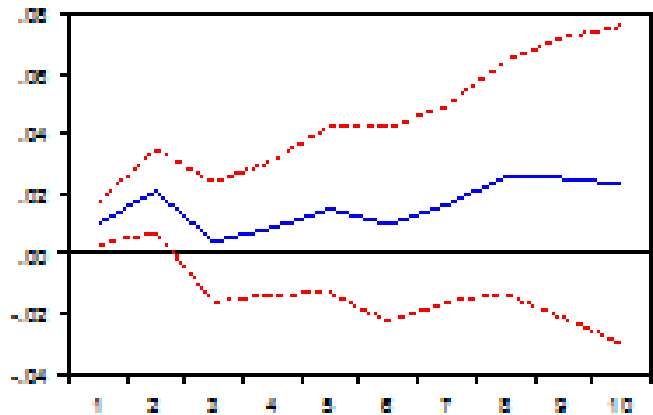

Figure 4(b). Response of LGDP to LTOUR

Further, response of tourism to HDI and GDP shocks are almost constant and taking 8 years period to settle down to its preshock level, see Figure 3(a) and Figure 3(b). Compared to the response pattern of HDI and tourism, response of GDP is more responsive to the shocks. Figure 4(a) shows that response of GDP to shock of HDI has negatively declined after 2 years and immediately increase in 4-year period. To the shock of tourism, GDP responses relatively with greater degree of volatility if compared with the shock of HDI, see Figure 4(a) and Figure 4(b).

\section{Conclusions}

This paper examines the relationship between human development, tourism and economic growth in Malaysia by employing annual data from 1998-2015. The results obtained from different cointegration approaches backing the hypothesis that the tourism is positively related to human development in the long run. The finding suggests that the known relationship may serve as a guide to policy makers to achieve better development of social and cultural in order to promote the growth. The finding also suggests that tourism industry may enhance the domestic human development through international tourists via dissemination of knowledge, managerial skills, and technology from abroad. The paper has some limitations. For instance, the study is limited to tourism and GDP variables. Future investigation may include more variables into the study. A similar procedure applied in this study can be duplicated in other countries. Future investigation may also consider others advance methodology to obtain more meaningful inferences.

\section{References}

Anderreck, K.L., Valentine, K.M., \& Knopf, R.C. (2007). A Cross-cultural analysis of tourism and quality of life perception. Journal of Sustainable Tourism, 15, 483-502.

Ankomah, P.K., \& Crompton, J.L. (1990). Unrealized Tourism Potential: The case of Sub-Saharan Africa. Tourism Management, 11, 610-616.

Aslan, A. (2013). Tourism development and economic growth in the Mediterranean countries: Evidence from Panel Granger Causality Test. Current Issues in Tourism, 17(4), 363-372.

Biagi, B., Ladu, M., \& Royuela, V. (2017). Human development and tourism specilaization. Evidence from a panel of developed and developing Countries. International Journal Tourism, 19(2), 160-178.

Department of Statistic Malaysia. (2016). Economic census. Kuala Lumpur: Department of Statistic Malaysia.

Haque, S., \& Chandio, J.A. (2013). Human Capital Flight in Pakistan: Strategies for Coping Brain Drain Situation. International Journal of Economics Business and Management Studies, 2(2), 75-82.

Johansen, S., \& Juselius, K.J. (1990). Maximum likelihood estimation and inference on cointegration-with applications to the demand for money. Oxford Bulletin of Economics and statistics, 52(2), 169-210.

Kadir, N., \& Karim, M.Z. (2012). Tourism and economic growth in Malaysia: Evidence from tourist arrivals from Asean-5 countries. Economic Research, 25(4), 1089-1100.

Kukreja, G., \& Alshirawi, A.A. (2014). Factors affecting business environment for investments: A survey of Bahraini businessmen. Journal of Asian Business Strategy, 4(12), 194-199.

Kum, H., Aslan, A., \& Gungor, M. (2015). Tourism and economic growth: The case of next 11 countries. International Journal Economics Finance Issues, 5(4), 1075-1081. 
Lean, H.H., \& Tang, C.F. (2010). Is the Tourism-led growth hypothesis stable for Malaysia? A note. International Journal of Tourism Research, 12(4), 375-378.

Lean, H.H., Chong, S.H., \& Hooy, C.W. (2014). Tourism and economic growth: Comparing Malaysia and Singapore. International Journal of Economics and Management, 8(1), 139-157.

Maciuliene, M., Skarzauskiene, A., \& Botteldooren, D. (2018). Developing a digital co-creation assessment methodology. Contemporary Economics, 12(4), 399-408.

Marrocu, E., \& Paci, R. (2011). They arrive with new information. Tourism flows and production efficiency in the European regions. Tourism Management, 32(4), 750-758.

Mohamed, B.M., Rasheli, G.A., \& Mwagike, L.R. (2018). Marginal Effects of Factors Influencing Procurement Records Management: A Survey of Selected Procuring Entities in Tanzania. International Journal of Social and Administrative Sciences, 3(1), 22-34.

Nana, A.E. (2017). Tourism: A promoter of human development. Unizik Journal of Arts and Humanities, 18(2), 192-210.

Njegovanovic, A. (2018). Hilbert Space/Quantum Theory of the Financial Decision and Role of the Prefrontal Cortex with a View to Emotions. International Journal of Social and Administrative Sciences, 3(1), 42-54.

Othman, R., \& Salleh, N.H. (2008). Relationship between tourism industry development and economic growth in major ASEAN countries. International Journal of Management Studies, 17, 171-188.

Rivera, M.A. (2017). The synergies between human development, economic growth, and tourism within a developing country: An empirical model for Ecuador. Journal of Destination Marketing and Management, 6(3), 221-232.

Sen, A. (1999). Commodities and capabilities. India: Oxford University Press.

Shafai, N.A., Nassir, A.M., Kamarudin, F., Rahim, N.A., \& Ahmad, N.H. (2019). Dynamic Panel Model of Dividend Policies: Malaysian Perspective. Contemporary Economics, 13(3), 239-252.

Sinclair, M.T. (1998). Tourism and economic growth: A survey. Journal of Development Studies, 34(5), 1-51.

Suresh, J., \& Senthilnathan, S. (2014). Relationship between tourism and economic growth in Sri Lanka. In S. Vijayakumar (Ed.), Economic issues in Sri Lanka (pp. 115-132). Jaffna, Sri Lanka: Guru Publisher.

Tang, C.F., \& Tan, E.C. (2015). Does tourism effectively stimulate Malaysia's economic growth?. Tourism Management, 46, 158-163.

Tanoos, J.J. (2017). East Asian trade cooperation versus US and EU protectionist trends and their association to Chinese steel exports. Asian Journal of Economics and Empirical Research, 4(1), 1-7.

United Nation. (2018). Human development indices and indicators. Washington D.C.: United Nations Development Programme.

Vanegas, M., \& Croes, R. (2003). Growth, development and tourism in a small economy: Evidence from Aruba. International Journal of Tourism Research, 5(5), 315-330.

World Bank Data. (2018). World development indicators. Geneva: The World Bank Group.

Zafarullah, M. (2018). VAT and Accounting Issues and Solutions in UAE. International Journal of Social and Administrative Sciences, 3(1), 35-41.

\section{Notes}

Note 1. Note that a similar outcome is also found in other countries, see United Nations (2018) and World Bank Data (2018) for details.

Note 2. By using geometric mean method, the scores calculated from a combination anchor of human development, namely being knowledgeable, decent standard of living, and healthy and long life, are aggregated to construct HDI, see United Nations (2018) for details. 